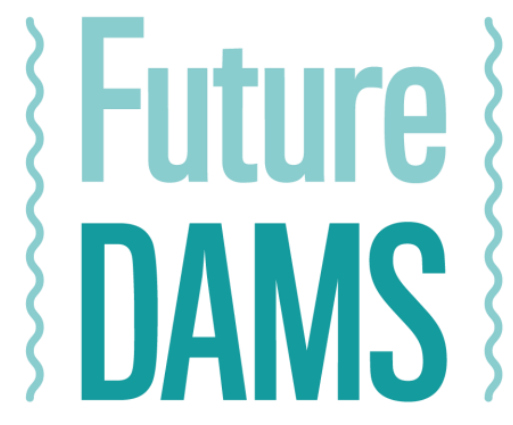

Design and Assessment of

water-energy-food-environment

Mega-Systems

\title{
Structural reform and the politics of electricity crises in Ghana: tidying whilst the house is on fire?
}

Barnaby Joseph Dye ${ }^{1}$

${ }^{1}$ Global Development Institute, University of Manchester, UK

\section{FutureDAMS}

\section{Working Paper 013}

November 2020

ISBN: 978-1-913093-11-2

Cite this paper as: Dye, B. (2020) Structural reform and the politics of electricity crises in Ghana: tidying up while the house is on fire? FutureDAMS Working Paper 0013. Manchester: The University of Manchester.

www. FutureDAMS.org 


\begin{abstract}
The 1990s 'good governance agenda produced a programme of change called the standard reform model. It involves privatising utilities, the creation of markets and the unbundling of electricity-system functions into formally separate, 'independent' regulated units. Pushed by the World Bank and others, elements of this programme have been widely adopted across developing countries, including in Ghana. However, Ghana, like many countries in Africa, continues to suffer from major power crises. In the past decade, the country has lurched from unprecedented shortages to electricity overabundance, entailing spiralling debt. Donors, researchers and policymakers in Ghana have pushed further privatisation and institutional-separation reforms as a solution. However, this paper demonstrates that, thus far, attempts to create good governance through the standard reform model have been overwhelmed by Ghana's politics. Using the political settlements framework, this article demonstrates how intense competition entailing an all-consuming focus on elections overcame the formal organisational separation and the inclusion of expertise in planning and operating the electricity system. Alongside high-modernist ideological beliefs in the power of megawatts to produce industrialisation, such competition created Ghana's crises of absence and abundance. The paper consequently highlights a disconnect between a continuing focus on the good governance model and the politics driving policymaking: too great a focus on democratic institutions, formal organisations and market motivations misses the importance of political power and how it manifests within ruling coalitions to shape governmental decision making. Greater questioning is therefore needed of the standard reform model and its assumptions about how to improve electricity outcomes.
\end{abstract}

\title{
Keywords
}

Electricity crises, governance, privatisation, politics, policymaking

JEL Codes O13; O21; O55; P41; P48; Q48

\section{Acknowledgements}

FutureDAMS is a consortium of over 30 researchers developing the knowledge base, tools and approach for designing interventions in systems to support resilient and sustainable development in a warming world. This work was supported by the UK Research and Innovation-Economic and Social Research Council [ES/P011373/1] as part of the Global Challenges Research Fund. 


\section{Contents}

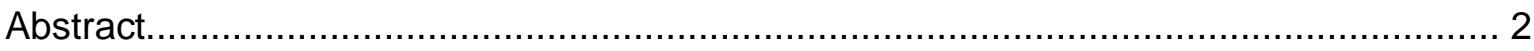

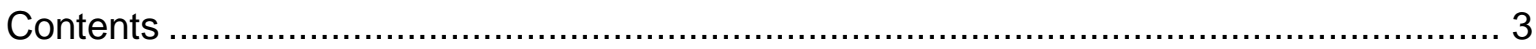

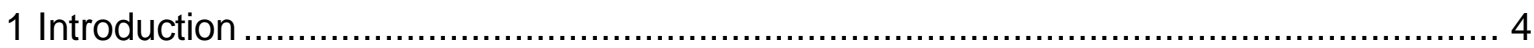

2 The history of structural reforms in development: reimagining the role of politics? ........ 6

2.1 Good governance and its application to the standard reform model....................... 6

2.2 The increasing attention to politics' role in development and the electricity sector ... 7

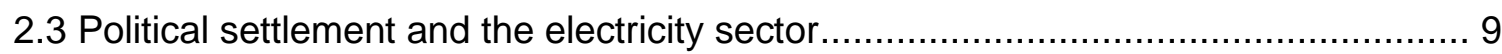

3 Ghana's political settlement: competitive, clientelist and short-termist.........................10

4 Ghana's two electricity crises: from absence to abundance ...................................13

4.1 The triple whammy behind dum-sor............................................................... 14

4.2 Dum-sor's long-term exacerbation of fiscal problems ......................................17

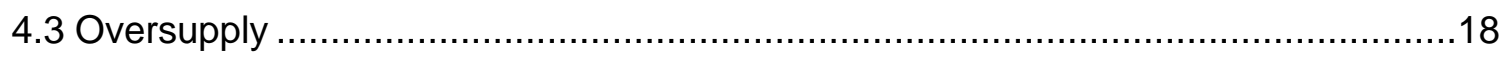

5 Understanding the underlying politics in Ghana's electricity crises ..........................21

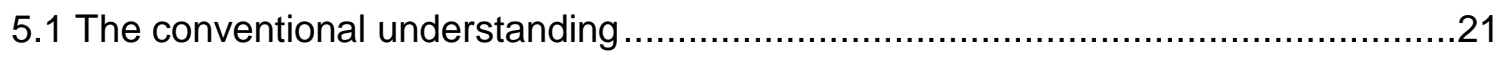

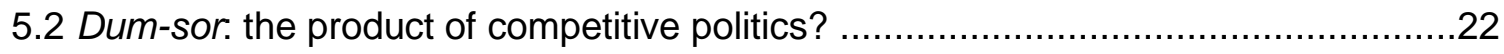

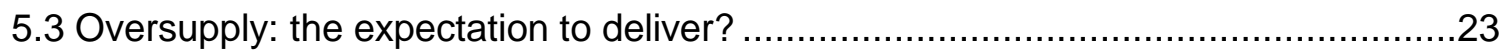

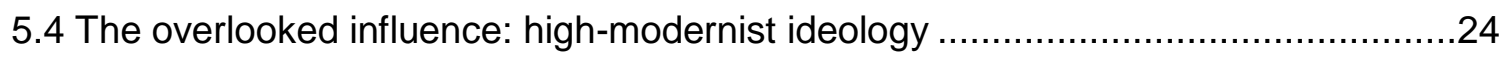

6 Conclusion: the standard reform model and the undermining of electricity planning ......25

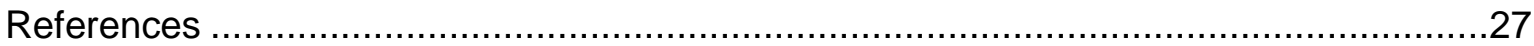




\section{Introduction}

On the 27th August 2012, a small group of pirates triggered the first of two major power crises in Ghana. Attempting to escape from the Togolese Navy on a captured oil tanker, the pirates left the ship's anchor trailing. It snagged on the West African Gas Pipeline, which transports Nigerian gas to Togo, Benin and Ghana. This sparked a major fuel shortage for some of Ghana's power plants, which combined with drought and fiscal issues to plunge the country into four years of electricity shortages and widespread load shedding. However, this crisis of shortage was quickly replaced with one of overabundance: Ghana went into a power plant construction overdrive, resulting in electricity-generation capacity equalling twice the country's demand by 2018. This increase is particularly problematic as it came from 'take-orpay' contracts that involve the government's distribution utility, the Electricity Company of Ghana (ECG), promising to pay private electricity companies typically for $90 \%$ of the power they make available, regardless of whether it is used. Ghana's large imbalance in supply and demand is leaving a costly bill, reaching 4\%-5\% of GDP in 2018 (World Bank, 2018).

Figure 1: Ghana's recent power surge and diversification

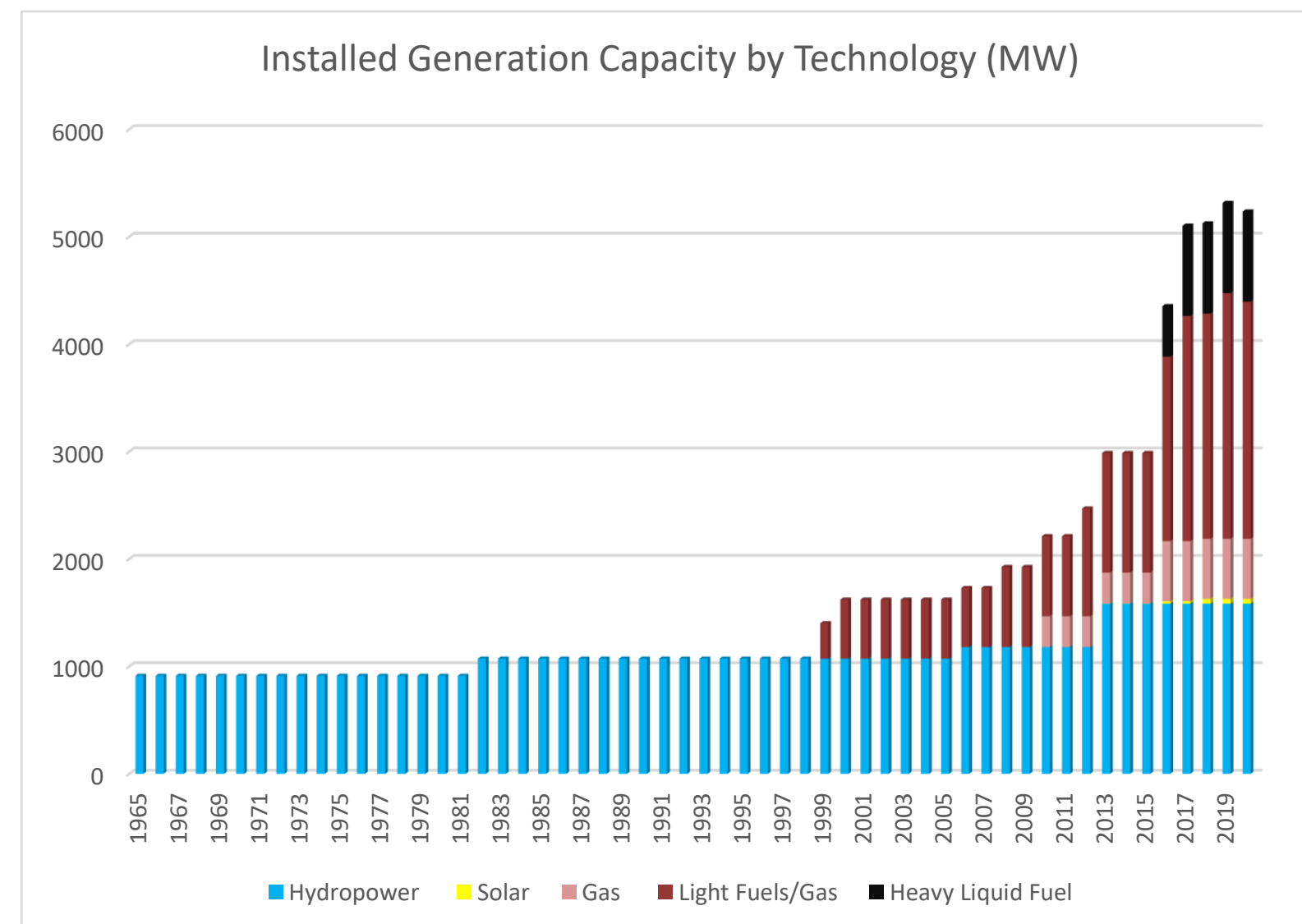

Source: Author's calculation using Energy Commission statistics.

Arguably, these crises are surprising. As shown in Figure 1, the country has diversified from hydropower to fossil fuels (gas and imported oil). Additionally, Ghana has adopted the majority of the recommended 'standard reform model' for the electricity sector, pushed by the World Bank from the 1990s across developing countries. In Ghana this has involved the unbundling of utility companies, introduction of corporate management, creation of two 
independent regulators, ${ }^{1}$ and growth of private generation companies. This paper demonstrates, however, how Ghana's underlying politics were always likely to overwhelm these formal institutional reforms, creating the conditions for the two electricity crises. In brief, individual and party-political interests, alongside ideological rationales, trumped longterm strategies and reduced the influence of professional planning.

This calls into question the underlying theoretical assumptions behind the standard reform model and the ongoing application of the good governance agenda in development and electricity policy. The agenda emerged from critiques of structural adjustment programmes in the 1980s, which argued that, alongside economic reform, 'apolitical' institutions were needed to ensure the 'rules of the game' were maintained, and property rights and markets could function efficaciously (North, 1990). The 'standard reform model' is the name given to the good governance agenda's application to the electricity sector. However, its underpinning theoretical assumptions, principally 'new institutional economics', have been widely criticised for their one-size-fits-all approach and their inadequate attention to the way political power shapes the functioning of institutions. This prompted the emergence of a new mainstream that involves greater appreciation of politics, as illustrated by Acemoglu and Robinson (2013) and North et al $(2009,2013)$. Such work is reflected in the electricity sector by academics (Ahlborg et al, 2015; Gore et al, 2019; Gregory \& Sovacool, 2019) and policy makers (Foster \& Rana, 2019; Lee \& Usman, 2018) who have advocated an increased appreciation of the political conditions enabling standard reforms. However, this approach has continued to focus chiefly on institutional separation and the introduction of the market. Thus, in Ghana, a number of donors and sectoral experts argue that, to address electricity crises and ensure financial stability, further reform is required with privatisation, unbundling and tariff changes ${ }^{2}$ to paraphrase Rodrik (2006), they just need to "get the prices and institutions right".

This paper argues that these mainstream understandings of the electricity sector fail to account for Ghana's electricity crises. It therefore asks the question: what caused the two crises of under- and oversupply? Its answer lies in the manifestation of political power in Ghana and the way this drives policymaking. Thus, questions of who has power in society, of its distribution and stability, are fundamental to understanding the politics of policy making in the electricity sector. Equally, the paper demonstrates the importance of ideology in rationalising over-optimistic investment decisions. To provide a theoretical grounding, the paper draws on research using Khan's (2010) theory of political settlements, and its refinement by others, particularly regarding the inclusion of ideas (Behuria et al, 2017; Gray, 2018; Lavers \& Hickey, 2016). Academic studies using the political settlement approach reveal Ghana's competitive, unstable system and the way this drives a short-termist, clientelist politics. Such use of political settlements advances the literature on the politics of development, as electricity reform has itself rarely been linked to ongoing debates about the evolution of good governance, or 'new' new institutional economics - see below (a partial exception being Gore et al, 2019).

\footnotetext{
${ }^{1}$ Of tariff setting and wider sectoral regulation

${ }^{2}$ They include interviewees from MCC, MIDA, the World Bank, JICA, as well as a former Minister of Energy.
} 
The paper is the product of research carried out between 2018 and 2019 that primarily involved conducting 49 semi-structured interviews with key electricity-sector experts in Accra and Kumasi. They included academics and researchers studying the sector, donor officials engaged in energy-sector programmes and civil servants from the utility companies - VRA, GRIDCo and ECG - and from the Energy Commission and Ministry of Energy. In addition, academic, policy research and government documents were examined. This helped create a database of projects, helpfully put together by Dr Simon Bawakyillenuo using official statistics (Energy Commission, 2014, 2019). Analysis followed an inductive, qualitative process of re-reading interviews and gradually discerning key themes so as to construct a timeline of policymaking and the key actors involved. The paper is not therefore a strict political settlements analysis, as these involve an archaeological approach that traces societal power, its social foundation and shifts over time. The paper proceeds by outlining the application of good governance ideas to structural reform of the energy sector and its recent mainstream evolution. It then outlines the alternative understandings of the politics of policymaking before shifting to examine the empirics of the two energy crisis in Ghana. This is followed by an analysis of the drivers behind these crises and their political foundations in high-modernist ideology and Ghana's political settlement.

\section{The history of structural reforms in development: reimagining the role of politics?}

\subsection{Good governance and its application to the standard reform model}

The good governance agenda took shape in reaction to the Structural Adjustment Programmes (SAPs) of the 1980s. With the assumption that profit motives could better allocate capital and increase economic efficiency, the SAPs centred on austerity, monetarist policies and the introduction of markets through deregulation and privatisation (Bayliss \& Cramer, 2003). However, by the 1990s, new institutional economics, particularly associated with North (1990), were calling for change. Critiquing the state's potential for inefficiency, new institutional economics uses a rational-actor model to argue that the interests of individuals within the civil service and political leadership are merely to maximise personal returns and/or maintain power. To achieve development, individuals' rational interests need to be aligned to longer-term goals. Thus, rather than the earlier SAPs' focus on 'getting the prices right' and introducing market reforms, now initiatives would additionally aim to 'get the institutions right', to build the governance structures enabling an efficient, free market (Rodrik, 2006). Crucial here were the disruption of patron-client relations through the creation of markets ruled by profit motives rather than state monopolies, and the separation and devolution of power. Democracy, rule of law and accountability were the new watch words: "political stability and economic development in developing countries [were assumed to stem from] ... institutions of political representation, accountability and market competition (Gray \& Khan, 2010, p 1).

This institutional turn in development also applied to the electricity sector. Having been largely overlooked in the 1980s SAPs, donors, especially the World Bank, began advocating sectoral restructuring in the 1990s (see World Bank, 1993). Gore et al (2019) and Lee and Usman (2018) described what became known as the 'standard reform model', involving seven policy themes (see Figure 2): regulated, transparent tariff setting; independent power 
producers (IPPs); corporatising, commercialising and ultimately privatising utility companies; the unbundling of generation, transmission, distribution and retail roles; the creation of wholesale, retail and generation markets; independent regulation; and underpinning legislation. The model therefore closely followed good governance rationales: it reduced the role of the state, introduced market competition and supposedly created accountability through independent regulation, while disrupting patron-client relations via the separation of powers and initiation of for-profit rationales. Competition and the 'right' institutions would create efficiency, better allocate capital and bring down power production costs while meeting consumer needs. The end-point in the model would be something akin to the UK's electricity sector, which is among the most unbundled and privatised in the world. Typically, this boiled down to prioritising unbundling, the separating out of the functions of generation, transmission and distribution into separate utility companies, and then privatisation of these utilities. With an independent regulator to ensure a level playing field, competition could then occur; multiple independent power producers (IPPs) would vie to sell electricity, while others could compete over concession deals to own and operate the grids transmitting and/or distributing electricity.

\section{Figure 2: The Standard Reform Model's Theory of Change}

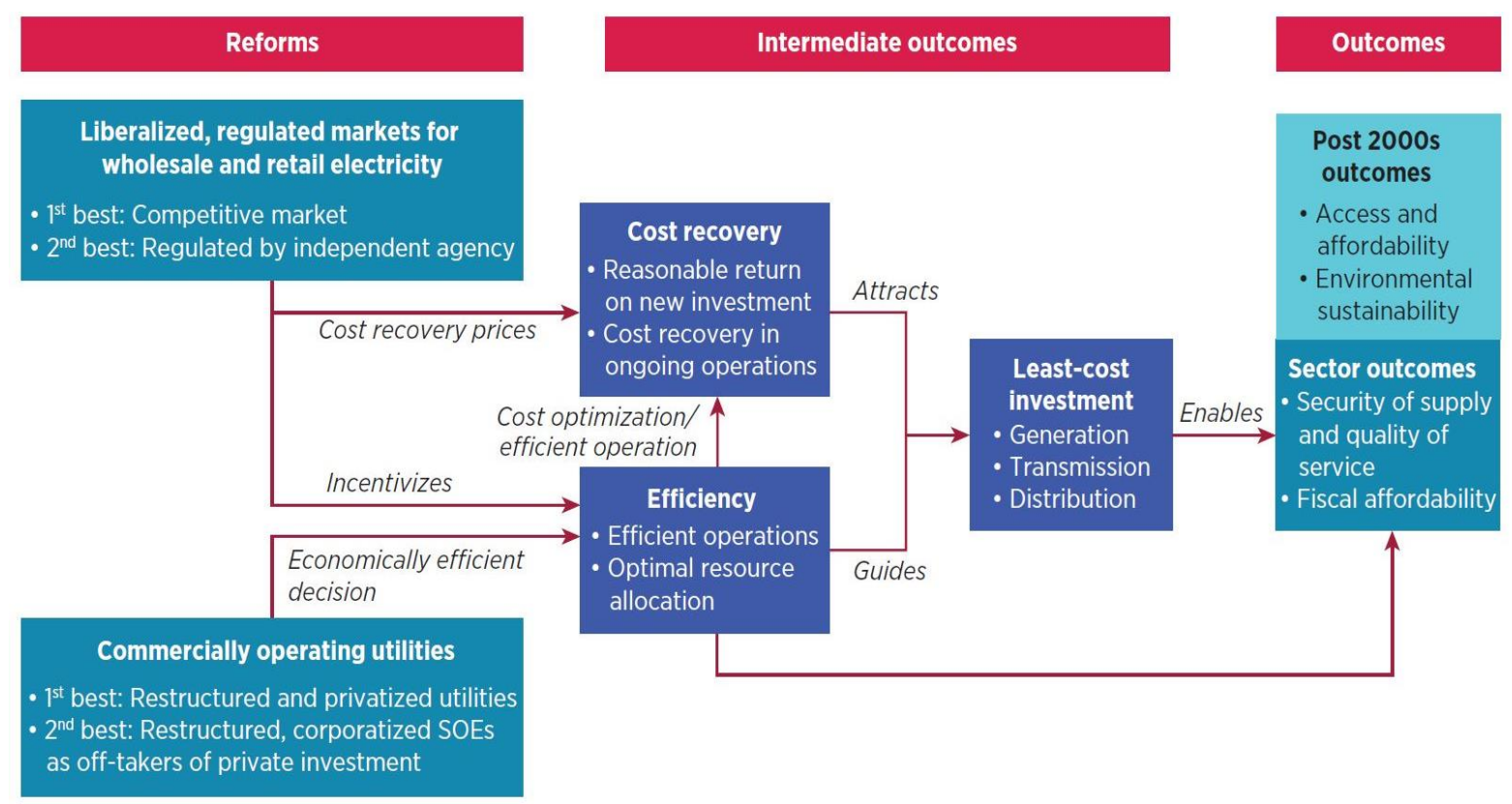

Source: Foster and Rana (2019, p. 5).

2.2 The increasing attention to politics' role in development and the electricity sector

However, since being gradually introduced over the 1990s and 2000s, the standard reform model has not resulted in the outcomes hailed by proponents. A recent World Bank report cited only 12 countries globally who took up all seven policy areas in full (Foster \& Rana, 2019). One of the most complete adopters in Africa (more so than Ghana) is Uganda, with fully unbundled utilities under private management. Although Uganda's electricity system is financially sustainable, with tariffs covering system costs, it entails a relatively high consumer tariff and limited investment in increasing electricity access (Gore et al, 2019; MacLean, Gore et al, 2016). In contrast, in the past 50 years, those countries who have engineered the 
largest economic rise, and built underpinning electricity systems, are Asian Tigers like Korea and Taiwan, and other East and Southeast Asian states ranging from China to Vietnam and Malaysia. These countries have adopted a very different political-economy model to SAP or good governance reforms, with far stronger state leadership, government economic intervention and degrees of authoritarianism (Chang, 2006; Gray, 2018).

The limited achievements of the good governance agenda, and the success of a more stateinterventionist model, prompted further evaluation of the role politics plays in development. There are two notable mainstream manifestations of this in Acemoglu and Robinson (2013) and North et al (2013), both of which look to further interrogate underlying political power structures. In brief, Acemoglu and Robinson (2013) identify the importance of what they term the 'political equilibrium' underpinning development. It is formed of inclusive institutions, ie those that defend universal rights to the rule of law and security of property, or = extractive institutions (those blocking new market entrants and creating unequal 'rules of the game' around property rights or the rule of law). ${ }^{3}$ North et al $(2009 ; 2013)$ present a similar 'access orders' theory. It categorises states according to whether they allow new market entrants through established universally applicable market rules (eg guarantees around property rights and equal treatment of companies by the state), and whether the ruling elite has a sufficient monopoly on violence to enforce this status quo. Gray (2018) argues that this represents 'new' new institutional economics, intellectually adapting to evidence about the state's role in creating development while continuing a focus on liberal-democratic institutions and assumptions about rational actors and the benefits of markets.

Research on electricity also increasingly asserts the important influence of politics (Dye, 2020a; Gregory \& Sovacool, 2019; MacLean, Gore et al, 2016; MacLean, Bob-Milliar et al, 2016). Frequently, this has manifested in assessment of the factors behind the official adoption and implementation of the standard reform model (Kapika \& Eberhard, 2013). For example, Gore et al (2019) assess the influence of donors, chiefly the World Bank, in pushing these reforms. Others alternatively see change resulting from 'political will' (Chineke \& Ezike, 2010) but this has been unpacked by recent World Bank policy studies. Alongside identifying technical factors such as a small grid size, ${ }^{4}$ being a middle-income economy and institutional capacity, these studies (Foster \& Rana, 2019; Lee \& Usman, 2018) show that a series of democratic institutions and norms are key to the adoption of the standard reform model. Their authors find that pre-existing political competition, decentralised government and market ideology have helped create trust in the benefits, and safety, of handing policymaking power to independent institutions and private companies. Additionally, they recommend paying close attention to a country's politics, the tailoring of policies to specific places and the use of political-influence analyses to identify local champions and convince the public.

Although these studies demonstrate a far greater emphasis on politics, they retain an underlying focus on institutions and an assumption that privatised, unbundled and transparent electricity markets represent the solution for sectoral financial sustainability,

\footnotetext{
${ }^{3}$ Such political equilibrium involves de jure - defined through brute force or other informal mechanisms - and de facto - that granted by formal institutions- power.

${ }^{4}$ Defined as below 1 gigawatt.
} 
reliable power supply and low energy costs. ${ }^{5}$ Despite recommending tailored approaches, Foster and Rana (2019) continue to promote the ultimate goal of a UK-style electricity sector and argue that, as a basis, countries should aim for full cost recovery using a transparent tariff-setting process, economically based power generation dispatch, corporatised utilities and competitively tendered IPPs. The discussion below demonstrates that actors in Ghana are similarly focusing on tariff setting and greater privatisation as solutions for the sector. Moreover, this recent inclusion of politics, whether in policy circles (Foster \& Rana, 2019; Lee \& Usman, 2018) or academia (Ahlborg et al, 2015; Chineke \& Ezike, 2010; Gore et al, 2019; Gregory \& Sovacool, 2019), pays less attention to the politics of the policymaking process itself but rather focuses on 'standard reforms' and institutions. This is partly because the recent literature largely continues, either implicitly or explicitly, to adopt the new institutional economics framework for understanding politics through rational-actor assumptions. The result, demonstrated in this paper's case study, is a limited ability to account for the key drivers behind electricity crises and fiscal issues. Ghana is perceived to meet many of the conditions indicated above: it has an established democracy with competitive elections; it is a middle-income economy; has the institutions for the rule of law; and has a relatively experienced and regionally respected electricity bureaucracy (at least in the VRA and GRIDCo). It has also adopted much of the standard reform model (Gore et al, 2019). ${ }^{6}$

\subsection{Political settlement and the electricity sector}

An alternative theoretical understanding comes from heterodox political economy. The past decade's most influential advance has been Khan's (2010) 'political settlements approach', which examines the distribution of power in society and the way this manifests to form a ruling coalition of business and political elites. Rather than focusing on institutions and security like 'new' new institutional economics, Khan's framework is premised on the idea that informal institutions and political processes are ubiquitous in developing countries; clientelist practices work outside formal institutions and yet are not necessarily detrimental to development. Patron-client relations and rent seeking were central to the economic growth of many of the rapidly advancing East Asian countries. Thus we need to have tools to assess the different types of clientelist politics and how they shape the possibilities for economic growth. Khan conceptualises two axes of power as particularly influential. ${ }^{7}$ The vertical axis assesses ruling groups' cohesion, pertaining to the challenge posed by junior levels within the coalition. The horizontal axis assesses the ruling coalition's societal dominance and how powerful excluded factions are (how likely or able they are to take power). The two axes of societal power allow the placement of political settlements in a typology that focuses on the level of societal control and the stability of the ruling elite in the face of internal and external competition.

This paper focuses on the influence of political settlements on policymaking. Coalitions that dominate society, that have weak competitors, and that are internally cohesive have numerous advantages. Their position of strength incentivises them to focus on longer-term

\footnotetext{
${ }^{5}$ Albeit state intervention is understood as important for electrification and carbon emissions

${ }^{6}$ Based on interviews and upcoming FutureDAMS research

7 In Khan's framework, called holding power which typically relates to control over key economic areas, political processes and large-scale organisational capabilities
} 
developmental goals in order to maintain their power over time and benefit members of the coalition. The stability of this political settlement allows the ruling business-politician group to invest slowly in long-term development and the creation of more effective bureaucracies. Cohesion within the ruling coalition also increases implementation capabilities, as it can ensure that key state and non-state actors follow the same agenda. Dominant, cohesive coalitions can also practise some disciplining against excessive rent seeking that doesn't support productive economic activity. Conversely, weaker clientelist societies, such as Ghana's, focus on short-term objectives. The plausible threat of being usurped from political power by an excluded rival faction requires a focus on winning and maintaining popular support. In democracies like Ghana, this means winning four-yearly elections. The ruling coalitions must also worry about internal contestation, with lower echelons able to mount challenges to usurp or obstruct those at the coalition's top. Again, this focuses rulers' attention on meeting the immediate needs of keeping their coalition together. The focus is therefore on using governmental power and rents to fight elections and to maintain the support of businesspeople, political financiers and the coalition's junior members. These pressures, and the political weakness of the incumbent faction, may also supress technical advice in policymaking. Short-term objectives that facilitate strategic personal and/or factional objectives are likely to trump consideration of the most fiscally or developmentally prudent actions, whether in choosing infrastructure investment, setting electricity tariffs or following merit-based recruitment.

The underlying political settlement therefore provides a framework for understanding the political pressures on the ruling coalition and governmental decision making. However, this type of analysis can tend towards simply aiming to place particular labels on countries, something that is arguably too reductive and unable to capture the dynamism of politics (Lavers \& Hickey, 2016). Therefore, the paper follows Behuria et al (2017) by using political settlements research as a tool for asking questions about the manifestation of political power and the dynamics of ruling-elite politics. Such an approach also allows critical treatment of Khan's work, particularly concerning the narrowness of 'holding power' and its presumption that the ruling elites know the policy choices that are in their strategic interest. As Lavers and Hickey (2016) point out, this presumption relegates ideas and ideology to the status of tools for winning support and thereby does not explain why some policies are chosen over others, when all might conceivably support the ruling coalition. This paper finds ideas influential in the substance of policymaking. Here, high-modernist-like ideas about the power of electricity to create economic growth and industrialisation mattered in rationalising the oversupply crisis and the creation of high megawatt targets. ${ }^{8}$ We now turn to providing an overview of Ghana's political settlement.

\section{Ghana's political settlement: competitive, clientelist and short-termist}

Broadly, Ghana may be categorised as having an unstable, competitive, clientelist political settlement (Abdulai \& Hickey, 2016; Mohan et al, 2018; Whitfield, 2018). It is characterised by competition between two long-standing political traditions that, despite changing their identity, have exchanged political power through elections and coups since independence. However, the country's political settlement has varied, experiencing stronger dominance

8 Dye $(2018,2020,2020 b)$ analyses as a key applied tenant of a high modernist ideology 
during periods of one-party and military rule. The longest of these came under President Jerry Rawlings (1981-2001), who was effectively a dictator from 1981 to 1992 . The introduction of democracy in 1992 has created a stable political settlement defined by open competition between the two major traditions, now formalised in two political parties, the National Democratic Congress (NDC) and the New Patriotic Party (NPP). Competition is intense but has been kept relatively peaceful, with the 'rules of the game' worked out by institutions such as Ghana's Inter-Party Advisory Committee (Nugent, 1999; Whitfield, 2009). Winning is key, given the degree of centralised presidential power in Ghana's winner-takesall form of government. Those excluded from power therefore have a strong incentive to throw all their resources into competing. This creates a status quo of fiercely fought elections both within and between political parties. Nationally, elections since 2000 have been won with small margins, with the winner only getting $0.2 \%$ to $3 \%$ over the $50 \%$ threshold. This partly stems from a stable political map, with Volta region and the North constituting NDC heartlands, the South, particularly the Asante region, being an NPP stronghold, while greater Accra and Central province are swing areas.

Table 1: Incumbent Presidents and Parties

\begin{tabular}{|l|l|l|}
\hline Incumbent President & Party & Years \\
\hline President Jerry J. Rawlings & NDC & $\begin{array}{l}1979 ; 1980-2000 \\
\text { Democratically elected } 1996\end{array}$ \\
\hline President John A. Kufuor & NPP & $2000-2008$ \\
\hline President John E. Atta Mills & NDC & $2008-2011$ (died in office) \\
\hline President John D. Mahama & NDC & $2011-2016$ \\
\hline President Nana A. Akufo-Addo & NPP & $2016-$ \\
\hline
\end{tabular}

Moreover, competition is also fierce within the parties (Nugent, 1999; Whitfield, 2018). With a constituency model, MPs in safe seats are not secure: given the lack of decentralised government, status as an MP is one of the few ways to gain local power and negotiate the government's geographic delivery of services (Abdulai \& Hickey, 2016; Whitfield, 2018).

The result, according to Whitfield's comprehensive political settlement-inspired research (2018), is a political economy defined by short-termism, regardless of who is in power. Without security, but with the need for MPs and President to finance elections and patronage networks, attention is overwhelmingly placed on immediate policies delivering financial and electoral advantage. The steep rise of election costs only adds to the short-term pressure. Research on the 2016 parliamentary elections (CDD \& WFD, 2018), for example, found an increase in costs of $58 \%$, with MPs spending US $\$ 85,000$ each on average to secure selection and election. This only increases the pressure to recoup money and reward financial backers once in office. Consequently, the state is used to reward party foot soldiers with jobs, and financial backers with contracts, subsidies and other special treatment (Abdulai \& Hickey, 2016; Mohan et al, 2018). Presidents, and incumbent MPs, can also maintain and increase their support - bringing physical development and material gain is a 
central strategy. This may be directly delivered by government projects, as demonstrated by Nugent's (1999) analysis of roads and other infrastructure. It is also evident in incumbent President Akufo-Addo's '1 village' pledges (eg 1 village ... 1 dam/1 factory/1 ambulance), which act to centralise the direction of small development projects otherwise involving local government. Banful (2011) has found more spending in the most contentious districts.

The Ghanaian government's finances thus face significant pressure. The World Bank has concluded that "the state plays the role of rent-seeker and distributer" in order to capture resources and direct them to party-political ends (World Bank Group, 2018, p 2). Such spending reaches a peak in election years, causing a recent post-election financial crisis (World Bank Group, 2018, p 32). The 2012 election saw a fiscal deficit amounting to 11.5\% of GDP, for example. This also matters for state agencies, given their role in providing public services. The formal rules governing their spending and sectoral regulation are frequently overridden in order to enable the targeted provision of contracts, jobs and public goods, such as water and electricity (Hirvi \& Whitfield, 2015). Moreover, as demonstrated in the case of electricity below, the state attempts to cut corners by not paying energy bills or providing promised funding, given pressures to reorient spending towards election-winning efforts. Overtime, this increases such agencies' debt and harms their ability to run efficient systems and infrastructure.

This has been particularly evident in decision making for the electricity sector over the past three decades. Statistical and qualitative analysis demonstrates that the incumbent influences the timings and geography of electrification (Briggs, 2012; Cuesta-Fernández, 2018). Another clear impact is on pressure to lower tariffs. According to the standard reform model, the creation of an independent regulator, the Public Utilities Regulatory Commission (PURC), in 1998 was supposed to prevent such manipulation (Wolf et al, 2007). However, the presidency's power to appoint the PURC's board, alongside its informal influence, has stymied this. Automatic tariff increases occurred between 2003-06 and 2010-2012 (Rupp, 2013) but these have been too contentious to sustain (Cuesta-Fernández, 2018;

Edjekumhene \& Dubash, 2002). Ghana is one of the few countries in Africa using business tariffs to subsidise household tariffs; in 2019, average household tariffs were $\$ 0.064$ per kWh against $\$ 0.138$ for businesses. ${ }^{9}$ Even when the PURC does announce increases, its lack of de facto power is signified by the presidency or Ministry of Energy overriding its policies, stating what the tariff will be and promising to pay the difference. ${ }^{10}$ In 2017 , for instance, the new NPP government, in line with campaign promises, announced reductions of $18 \%,{ }^{11}$ leaving a 9\% gap between prices in 2016 and those in 2019. ${ }^{12}$ Similarly the NDC stopped an automatic tariff increase in the 2012 election year (World Bank, 2012). Therefore, tariff setting is "a black box" and subject to political interference. ${ }^{13}$ As one interviewee explained, the head of the PURC "goes to see the President beforehand"; ${ }^{14}$ they "don't want to upset their friend the President". ${ }^{15}$ Formal separation of powers and the transparent processes of

\footnotetext{
${ }^{9}$ As calculated by GlobalPetrolPrices.com (accessed 26/6/2020)

10 Interviews, Researcher, Kumasi; Researcher, Kumasi

11 Interviews, Senior Official, MiDA; World Bank, 2018

12 Interview, Senior Official, MiDA

13 Interview, Planner, ECG

14 Interview, Ex-Minister, Ministry of Energy

15 Interview, Senior Planner 1, Energy Commission
} 
the PURC are usurped by the de facto power of the presidency and its attachment to appeasing voters.

Overall, then, the literature analysing Ghana's political settlement suggests that a strong short-termism prevails in policy making by both competing factions. Additionally, it indicates that, where possible, investment, jobs and public services resulting from the electricity will be bent towards obtaining an electoral advantage. Thus, accountability mechanisms and any formal institutional separation are trumped by the concentration of power in the presidency, the informal status of politicians and by parallel forums which negotiate the 'rules of the game' between political parties. The above suggests, in line with Whitfield (2018), that this political settlement persists through changes of government between the two factions. Whitfield goes further, however, arguing that this continuity means that ideological differences between the self-professedly centre-left NDC and the centre-right NPP matter only in rhetoric and for galvanising their base, not in policymaking. This contrasts with analysis of earlier governments in Ghana, particularly that of its founding President, Nkrumah. A number of academics analysing the Akosombo Dam scheme see the project as high-modernist, influenced by a belief that the dam represented modernity in the country and that it would linearly bring development by replacing traditional farming with modern technology and electricity (Hoag, 2013; Miescher, 2014). The following sections assess whether such ideological influences continue, turning to an empirical analysis of Ghana's electricity sector. This starts with a brief overview of Ghana's history of standard reform of the electricity sector before proceeding to an analysis of the two electricity crises. The explanations for these crises are then assessed, with the paper contrasting the conventional, good governance approach with its analysis of the politics of policy making in Ghana.

\section{Ghana's two electricity crises: from absence to abundance}

Ghana works as a case study to test the good governance model's underlying assumptions partly because both its political parties have been relatively keen adopters of the standard reform model. Unlike in many countries in Africa, the majority of distribution, covering the south of the country, was separated from the main utility, the Volta River Authority, in 1967, creating the Electricity Company of Ghana (ECG). ${ }^{16}$ The government embarked on market reforms only after the World Bank made it a condition for financing a new thermal power plant in 1993 (Gore et al, 2019). This produced the 1994 Strategic Framework for Power Sector Development Policy. However, Ghanaian actors shaped the implementation and details of this reform. In 1997, they rejected the World Bank's preferred consultant and drove change through a Power Sector Reform Committee, selecting a Chilean firm to provide support (Edjekumhene et al, 2001; Edjekumhene \& Dubash, 2002). The committee also rejected the World Bank's formula for selecting tariffs. By 1998, the government had partially implemented the committee's recommendations: IPPs were legally introduced and two regulatory agencies were formed, the Energy Commission, an arms-length regulator for licensing IPPs and advising government, and the Public Utilities Regulatory Commission (PURC), supposed to be completely independent and charged with approving Power Purchase Agreements with IPPs, and with consumer tariff setting (Wolf et al, 2007). Further change came in 2006, with transmission and system-management functions handed from

${ }^{16}$ Officially incorporated in 1963 but enacted by a 1967 government decree 
VRA to a new state-owned company, GRIDCo. According to the standard reform model, this should have put Ghana's electricity sector in a strong position, with the separation of the different institutions ensuring the influence of technocratic management, efficiencies and prudent investment decisions. However, as shown below, undertaking standard reforms did little to improve electricity-sector decision making and did not fundamentally change the politics of policy making. While the first power crises had external triggers, governmental decisions underpinned by political rationales deepened these, creating a power shortage, and later a significant fiscal hole.

\subsection{The triple whammy behind dum-sor}

Ghana has experienced previous power shortages, ${ }^{17}$ but the $2012-16$ episode represented a new level, earning the Akan nickname dum-sor meaning 'off and on', or even dum-dum ('off and off'). The economic impacts were severe. In 2016 alone, dum-sor caused an estimated GDP loss of \$320-924million - 2.6\% of Ghana's GDP (Eshun \& Amoako-Tuffour, 2016; Kemausuor \& Ackom, 2017, p 4) ${ }^{18}$. As outlined at the start of this paper, the immediate trigger for dum-sor was the West African gas pipeline's rupture. This, combined with Ghana's absence of liquefied natural gas (LNG) infrastructure, knocked out the exclusively gas-fuelled plant Sunon Asolgi (200MW) until the pipeline was fixed in 2014 (Acheampong, 2016; Eshun \& Amoako-Tuffour, 2016; Kemausuor \& Ackom, 2017) ${ }^{19}$. A compounding factor was below-average rainfall in $2012 .{ }^{20}$ Hydropower's contribution to electricity generation fell, particularly after 2014, following a five-year period of heavy reliance, leading to reservoir overuse, as illustrated by Figure 3 (Oxford Business Group, 2017). ${ }^{21}$

\footnotetext{
17 In 1982-85, 1998-2000 and 2006-2007

${ }^{18}$ See also surveys of impact on small business and destruction of hospital and industrial equipment (e.g. Rupp, 2013)

19 Interviews, Senior Managers 1\&2, VRA; Senior Planner 1, Energy Commission

${ }^{20}$ Even claiming that the Volta reservoir went below minimum operating level for a time, although this could have been because of overuse rather than the rainfall (Interview, Researcher, Energy Think Tank)

${ }^{21}$ Interview, Senior Planner 1, Energy Commission
} 
Figure 3: The high use of hydropower until 2014 and stagnation in thermal power until 2015 as shown by power generation listed by technology in $\mathrm{GwH}$.

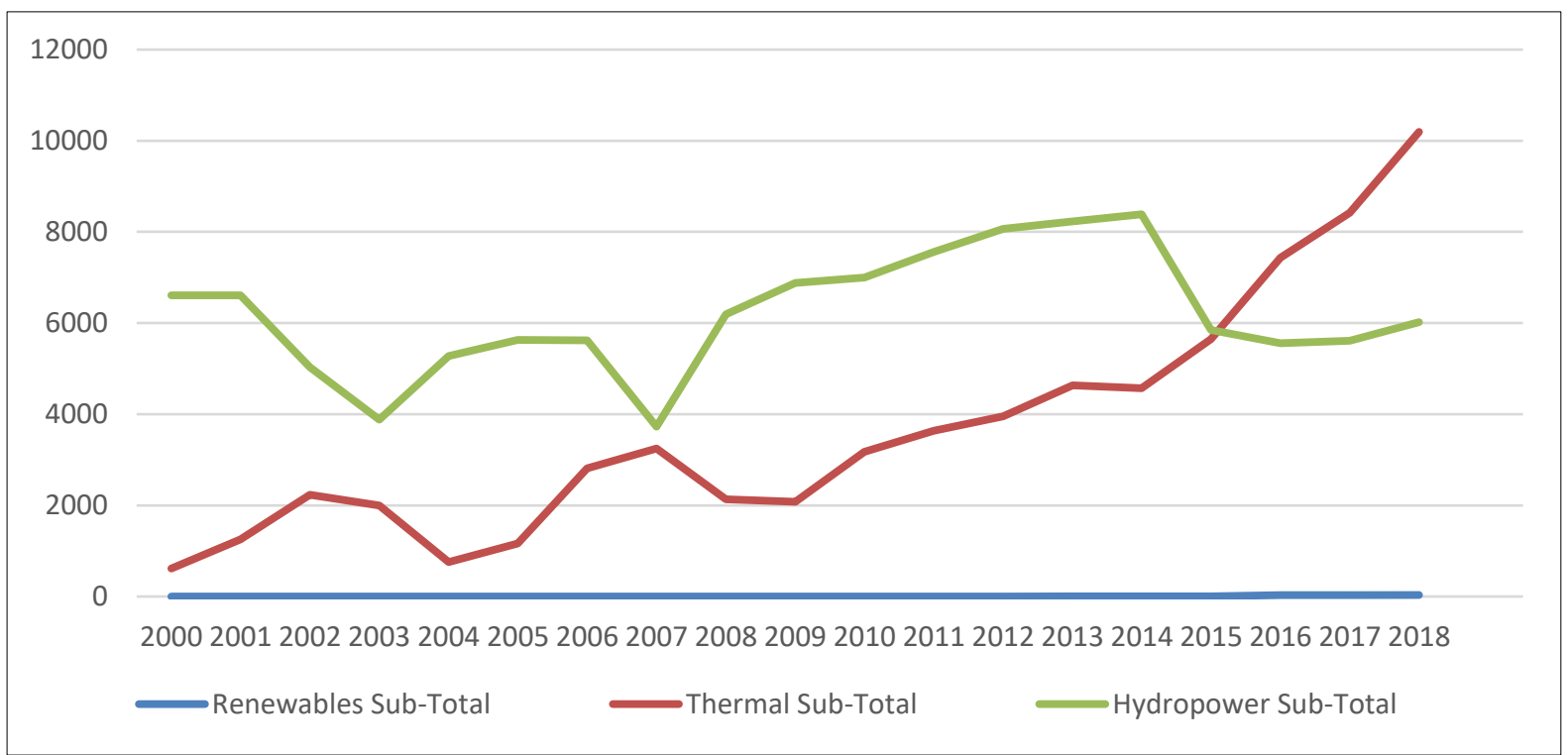

Source: Author's calculation using Energy Commission statistics.

The country's remaining thermal capacity of $1,003 \mathrm{MW}$ in $212(1,113 \mathrm{MW}$ by 2013$)$ was able to run using imported light or heavy crude oil, with only 287MW exclusively dependent on gas. ${ }^{22}$ However, both these fuels are typically more expensive than pipeline gas, especially as they had to be bought on the spot market, whose prices were rising in line with the boom in commodities until 2014 (Kemausuor \& Ackom, 2017). ${ }^{23}$ The expense of averting the power crisis was significantly worsened as the norm for Ghana's Power Purchase Agreements (PPAs) with private companies designated ECG, via VRA, as the fuel provider. ${ }^{24}$ While this does reduce the risk for incoming investors, this choice burdened the ECG and VRA utilities with extra fiscal strain. ${ }^{25}$ ECG proved unable to cover these costs and became increasingly indebted to VRA for fuel delivery. Officials stated that light crude cost $\$ 140$ a barrel, ${ }^{26}$ making the equivalent of three weeks supply $\$ 400$ million. ${ }^{27}$ On top of this, VRA needed to run emergency jet-engine generators to cover the peak demand, a more expensive fuel option. ${ }^{28}$ VRA paid $\$ 2.2$ billion for light crude over four years (Adam \& Boakye, 2014). A lack of payments between utilities and between the utilities and the powerproducing companies was therefore plunging the country into a power crisis. Crucially, the ministries of energy and finance provided only limited support: in May 2012, the VRA requested finance for six cargoes of light crude to make up for the lost gas but the government only provided three. ${ }^{29}$ Moreover, only US \$107 million of the US \$937 million

\footnotetext{
22 Author's statistics compiled from Energy Commission $(2014,2019)$

23 Interview, ex-CEO, GRIDCo

24 Interviews, Senior Manager 1, VRA; Interview, Senior Planners $1 \& 2$ and Planning Team, Energy Commission; Interview, ex-CEO, GRIDCo

25 Interviews, Senior Planners 1\&2, Energy Commission; Interview, Senior Manager 1, VRA

26 Interview, ex-CEO, GRIDCo

27 Interview, Senior Planner 1, VRA

28 Interview, Senior Manager 1, VRA

29 Official Letter from VRA to Energy Ministry ("Light Crude Oil Support for VRA in 2012", 13"

September, 2012)
} 
light crude purchased by VRA between November 2012 and January 2015 came from government promissory notes. ${ }^{30}$

Figure 4: Generation (GwH) vs installed generation (MW), illustrating the fall in generation during the dum-sor period against rising power-generation capacity

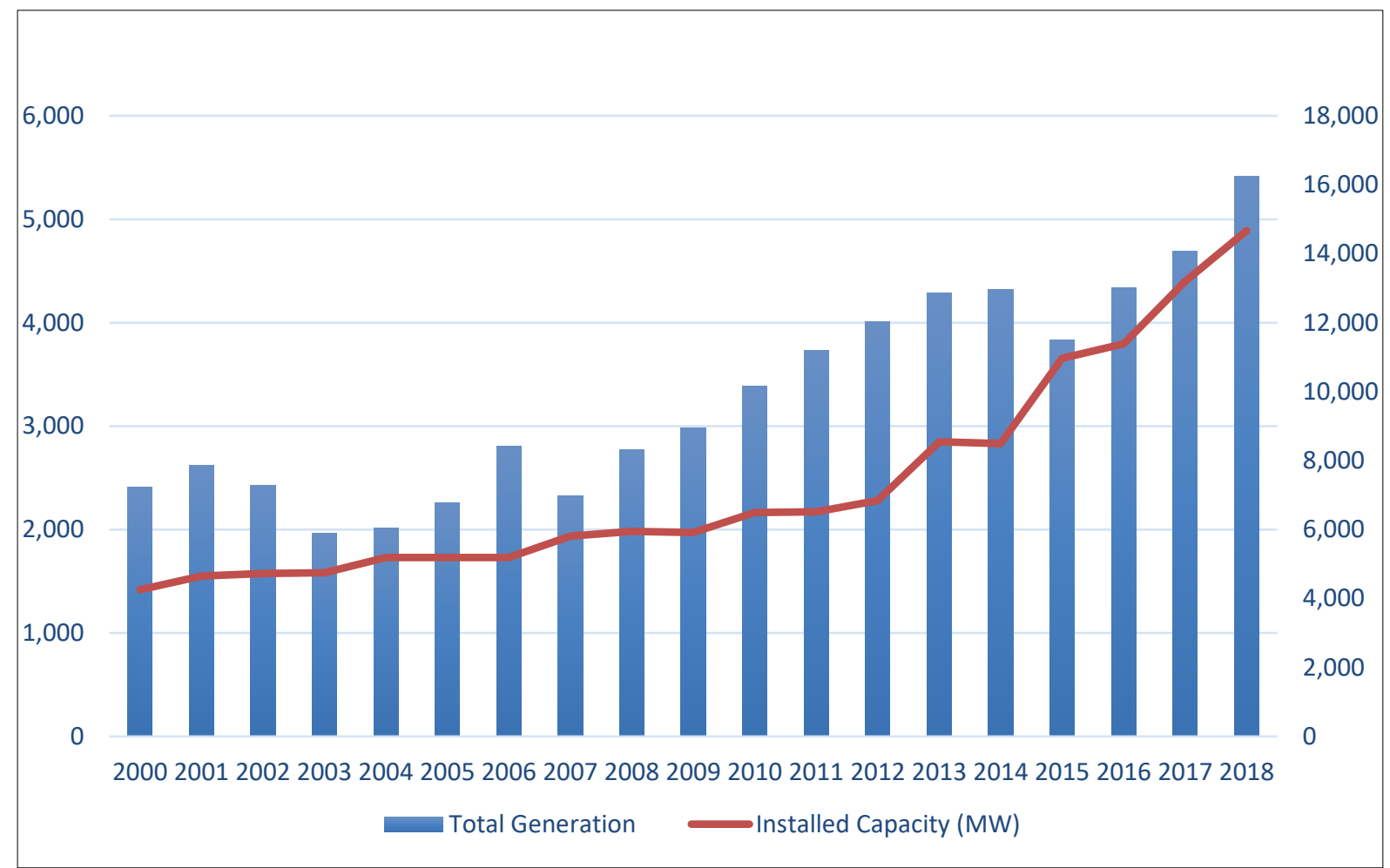

Source: Author's calculation using Energy Commission statistics.

The VRA and IPPs were therefore unable to run their plants at full capacity because they didn't have enough money. Thus, many commentators conclude that dum-sor was "baffling" and "not necessary". ${ }^{31}$ "If [all the thermal] plants were going [Ghana] would have been OK. The challenge was fuel." "I2 "It was a capacity constraint too but came a time when they had enough so [the key issue] was fuel." 33 This argument is reinforced since, in 2012, another IPP, Cennit (126MW, sometimes called TT2PP), was commissioned alongside an expanded $132 \mathrm{MW}$ at the VRA's Takoradi III plant, increasing thermal capacity to 948MW. Then, in 2013, the TICO plant was expanded and Bui Hydropower Dam also came online, adding $510 \mathrm{MW}$. Figure 4 demonstrates how generated power stagnated and fell between 2012 and 2016, while installed capacity rose: "[there was capacity but] not enough money to buy fuel". ${ }^{34}$ Therefore, Ghana had enough plants to cover electricity demand. However, the

30 Official Letter from VRA to Energy Ministry ("Submission of Status Reports of Handing-Over Notes", $19^{\text {th }}$ December, 2014)

31 E.g. Interview, Senior Manager 1, VRA; and a planner, ECG.

32 Interview, Senior Planner 1, Energy Commission.

${ }^{33}$ Interview, former Minister of Energy. This was echoed in interviews with researchers in Accra and Kumasi, and with Senior Planner 1, VRA.

34 Interview, Senior Planner 1, Energy Commission. 
government and the utility companies were unwilling or unable to provide the money to purchase sufficient fuel. This financial position has deeper political roots stemming from the political settlement.

\subsection{Dum-sor's long-term exacerbation of fiscal problems}

In addition, Ghana's political dynamic caused longer-term fiscal issues in the utilities that significantly hampered their ability to purchase the fuel to prevent dum-sor. This issue started in distribution functions. Figure 5 depicts the significant losses.

Figure 5: ECG's distribution, combining technical and distribution losses

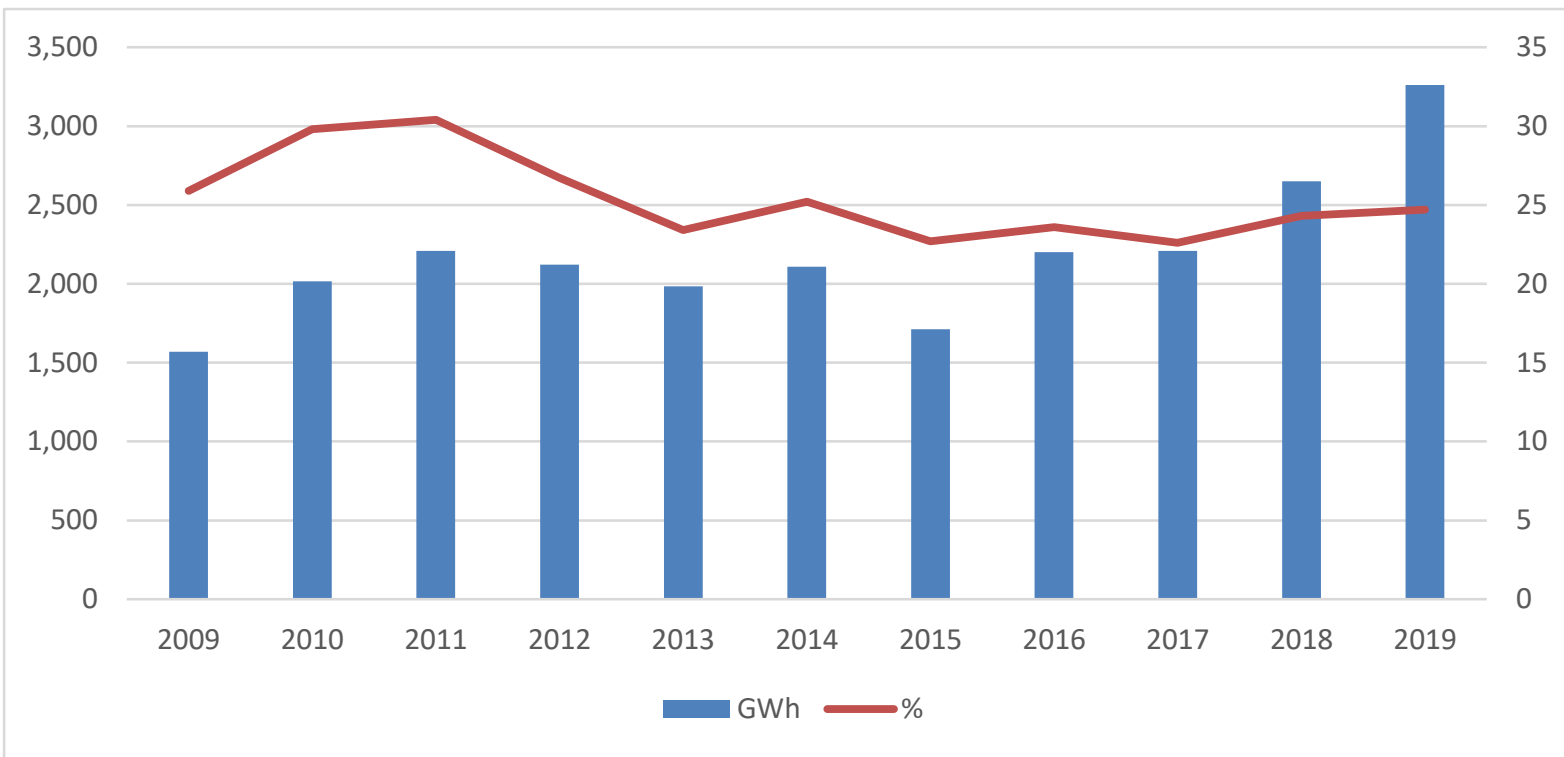

Source: Author's calculation using Energy Commission statistics.

The losses have reduced ECG's revenue, contributing to the utility's substantial deficit of around $\$ 800$ million a year. ${ }^{35}$ Technical losses are those resulting from the inefficiency of distribution lines and from faulty or old equipment. ${ }^{36}$ The situation has been worsened by the aforementioned drive to electrify the vast majority of Ghana, something that necessarily decreases the system's efficiency. Moreover, as the above discussion has shown, political rationales, rather than an efficiency model, influenced decision making over how and where to undertake electrification grid-infrastructure expansion. On top of this are commercial losses caused by illegal tapping and incomplete bill collection (Kemausuor \& Ackom, 2017), ${ }^{37}$ but most important is non-payment by state agencies and federal ministries. Although ECG is officially separate and supposed to be run commercially, government institutions know that "they don't necessarily have to pay for the electricity as they can't [be taken off-line]"; "you can't cut them". ${ }^{38}$ Despite attempts by the Ministry of Finance to give

\footnotetext{
35 Interview, officials, JICA.

36 Interviews, officials, GIZ; researchers, Accra; and researcher, Kumasi.

37 Interviews, researchers, Accra.

38 Interviews, Senior Planner 1, VRA and former Minister of Energy: Also supported by: Officials, GIZ; Senior Planners $1 \& 2$ and Planning Team, Energy Commission; Senior Manager 2, VRA; Senior Officials 1\&2 World Bank; Senior and Junior Planners, ECG.
} 
specific electricity bill budget lines or pay bills directly to ECG, ${ }^{39}$ the government's total arrears are $\$ 2.7$ billion. ${ }^{40}$

Market mechanisms, democratic norms and organisational separation and corporatisation were unable to operate, and therefore did not prevent this issue, because of Ghana's political settlement. The overview above has demonstrated the pressure on ministerial budgets to divert state resources to elections, creating a predictable debt issue thereafter. Additionally, the analysis above records interventions by government to prevent tariff increases that would improve ECG's budget, again in order to appeal to voters. The result is insufficient revenue for ECG to pay power producers, something that arguably harms VRA in particular because, as a state agency, it is easier to default on payments to it; officials there stated that "we all know that one of the main problems [with our budget] is ECG", ECG "defaults a lot" and VRA is rarely paid on time. ${ }^{41}$ VRA consequently borrows from the market repeatedly (World Bank, 2018) and receives money from the World Bank and government to meet short-term costs (Eshun \& Amoako-Tuffour, 2016). ${ }^{42}$ This situation has been worsened by poor enforcement of transactions between government entities, ${ }^{43}$ but has particular ramifications for the supply of gas: VRA is responsible for paying Nigeria for the West African Pipeline supply but its repeated defaults caused "erratic supply until 2017/18". 44 The use of Ghana's own domestic gas has only been possible since 2019, with the reversing of the gas pipeline so that it can flow from Ghana's oil fields in the West to the Tema gas plants in the East. Overall, interventions in regulation, the diversion of budgets and infrastructure construction have worsened the electricity sector's fiscal position over time. Therefore, despite abiding by democratic norms and adopting a market ideology, the standard reform model has been overwhelmed by party-political interventions, resulting in Ghana's utilities being unable to address the dum-sor fuel shortage. The following sections analyse the role of Ghana's political settlement in driving this, but first we turn to the second crisis.

\subsection{Oversupply}

Following dum-sor, President Mahama's administration inadvertently set another crisis in motion. Between 2014 and 2016, the government orchestrated 43 new PPA deals (World Bank, 2018) ${ }^{45}$ taking total power capacity to over 5,000MW (see Figure 5). This process was government-led, bypassing official processes. Officials have described how the newly created Ministry of Power in 2014 usurped the normal IPP contracting process, excluding the

\footnotetext{
39 Interview, Senior Official 1, World Bank.

40 Interview, Senior Official 2, World Bank.

41 Interviews with Energy Think Tank researchers; a senior official, MiDA; and ex-CEO, GRIDCo.

42 Interview, Senior Manager 1, VRA.

${ }^{43} \mathrm{Eg}$ non-implementation of a waterfall payment system. Interviews, Senior Planners 1 and 2, Energy Commission; Senior Planners 1 and 2, VRA.

44 Interview, Senior Manager 1, VRA. This was echoed in interviews with a researcher, Accra; Senior

Planner 1, VRA; a researcher, Energy Think Tank; and Senior Planner 2 and Planning Team, Energy Commission.

${ }^{45}$ And 55 licences under review by the Energy Commission. Interviews, officials, GIZ; Senior Officials 1 and 2, World Bank; Senior Official, World Bank.
} 
Energy Commission, GRIDCo and ECG, despite the latter officially signing the PPAs. ${ }^{46}$ First, existing IPPs such as Sunon Asolgi were asked to increase installed capacity. Then, the ministries negotiated with new companies, ${ }^{47}$ although reports and interviewees indicate little to no due diligence was carried out. ${ }^{48}$

Ostensibly, this dramatic contracting of generation plants fitted an official target of 5,000MW by 2015 in the National Energy Act 2010 (Ministry of Energy, 2010). However, the contracting did not follow the project or construction timeline: the 2010 act features a number of hydropower plants, including the Brazilian-government-backed Juale Dam (90MW) and the Micro-Hydro Western Rivers Scheme (625MW). In contrast, the new PPAs were almost all thermal plants commissioned in 2016 and 2017. Thus, although reaching a predetermined ministerial target, the official, technician-led planning process had not occurred. The 'independent' regulatory agencies and technical utilities had different predictions. The Energy Commission's 2006-20 plan was for 3,000-4,000MW by 2020 (Energy Commission, 2006), while VRA's predictions and GRIDCo's forecasts agreed that demand would near $3,000 \mathrm{MW}$ by $2020 .{ }^{49}$ However, and unusually, the Ministry of Energy usurped VRA's and GRIDCo's officially mandated planning role and the Energy Commission's independent vetting and approval function; as one official stated: "some [PPAs are] not official but in the system anyway". ${ }^{50}$ Thus, the ministry rapidly implemented the 2010 target against advice and planners' demand-forecasts, usurping their formally assigned roles.

Figure 6 demonstrates how electricity supply fell widely out of step with demand. In 2016, capacity was under $3,000 \mathrm{MW}$ against roughly $2,000 \mathrm{MW}$ in demand..$^{51}$ This grew to $5,000 \mathrm{MW}$ by 2017 , with demand roughly $2,500 \mathrm{MW}$ by 2018 and $3,115.2 \mathrm{MW}$ in $2020 .^{52}$ This gap presents a challenge, as the supply increases came almost universally through private sector deals, where the industry standard in Africa is to de-risk investments using 'take or pay' deals involving ECG paying for $90 \%$ of the power made available. The Ministry of Finance underwrote the deals with sovereign guarantees, rushed through parliament. ${ }^{53}$ The easiest mitigation for electricity oversupply, and an aim of the 2010 plan, is for Ghana to become a regional power exporter across international transmission lines. However, this hasn't materialised, partly because of a lack of infrastructure, ${ }^{54}$ but also because neighbouring countries want to achieve their own energy independence, not least given past experiences of being cut off during Ghana's power shortfalls (World Bank, 2013). ${ }^{55}$ Equally

\footnotetext{
${ }^{46}$ Interviews, Senior Planners 1\&2 and Planning Team, Energy Commission; Senior and Junior Officials, Renewables, Ministry of Energy. "Ministers acting independently" (Interview, Senior Planner, ECG)

47 Interviews, Senior and Junior Officials, Renewables, Ministry of Energy; ex-CEO, GRIDCo; Senior Officials 1 and 2, World Bank. Eight new IPPs have come online.

${ }^{48}$ Eg the Parliamentary Committee to restructure the Build Own Operate and Transfer Deals' 2017 report on Ameri; and Senior Planner 1, Energy Commission.

49 Interview, Senior Planner 1, VRA.

50 Interviews, Senior Planners 1 and 2 and Planning Team, Energy Commission.

51 Interview, Senior Manager 2, VRA.

52 Interviews, Senior Planner 2 and Planning Team, Energy Commission; and Energy Commission

Statistics, 2020.

53 Interview, former Minister of Energy.

${ }^{54}$ Medium capacity lines link Ghana with Cote d'Ivoire, Burkina Faso, Togo and Benin. A high capacity line to Burkina Faso and Mali is under construction.

55 Interview, former Minister of Energy.
} 
problematic is Ghana's high electricity tariff which, boosted by the new PPA deals, makes its electricity unattractive.$^{56}$ Consequently, neighbours like Togo and Benin are building their own plants: the government "did not do due diligence on other countries who were building plants". ${ }^{57}$ The result is a deepening of debt in Ghana's energy utilities. Interviewees backed up reports putting ECG's annual deficit at $\$ 580$ million (Dzawu, 2020), ${ }^{58}$ while the World Bank (2018, p 13) recorded that in 2018 overcapacity payments had reached $\$ 680$ million, 4\%$5 \%$ of GDP, for the roughly $1,900 \mathrm{MW}$ of spare capacity. Reportedly, by July 2020 , unpaid bills to the IPPs were reaching $\$ 1.4$ billion (Dzawu, 2020).

Figure 6: The exponential increase in IPPs against the steady rise electricity demand

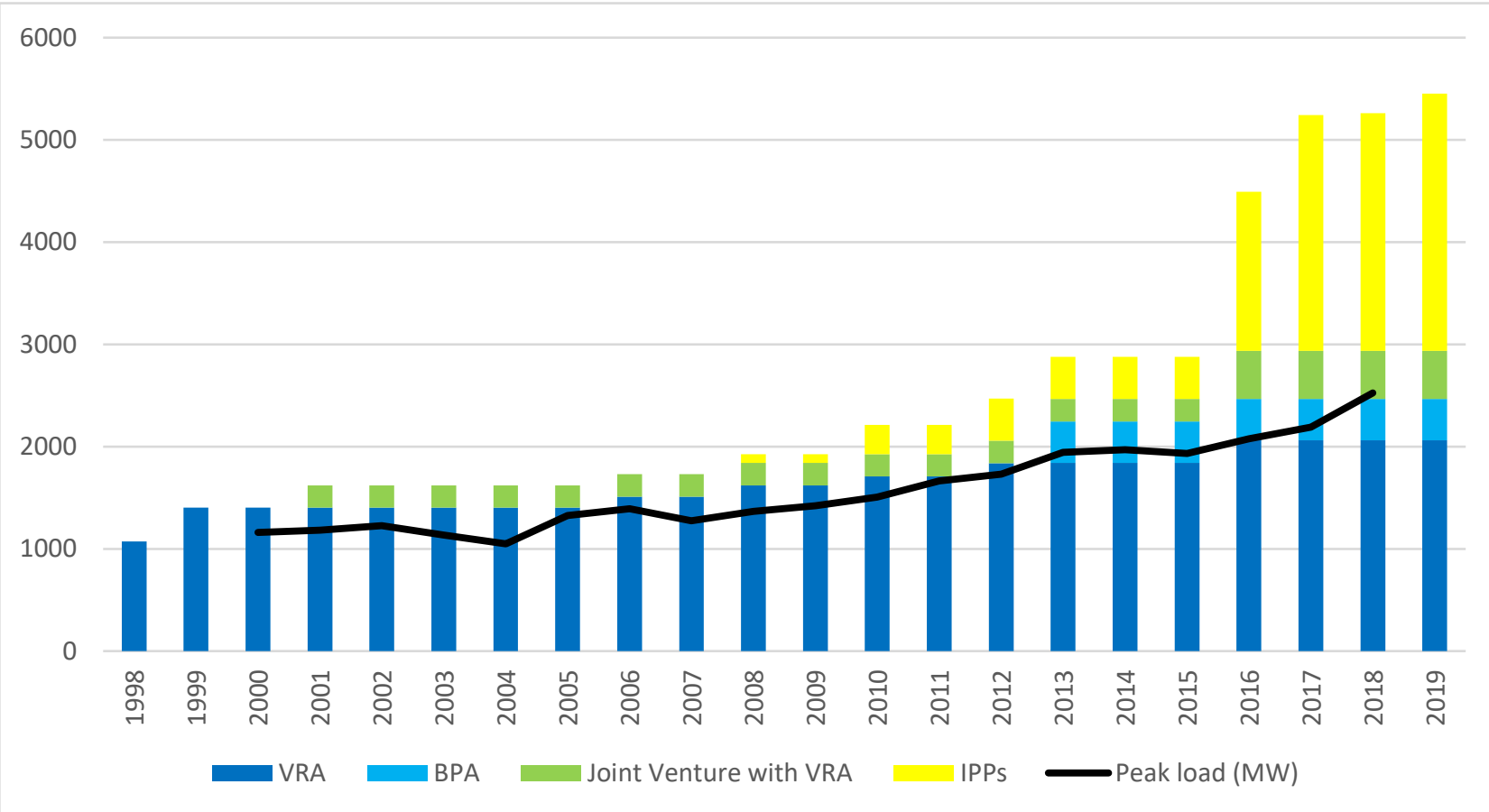

Source: Author's calculation using Energy Commission statistics.

A similar process happened with liquefied natural gas (LNG). A separate Ministry of Petroleum (until 2017) and state organisation, Ghana's National Gas Corporation, signed take-or-pay contracts to buy gas and build associated infrastructure. ${ }^{59}$ Most prominent is the Sankofa Agreement involving payment for $90 \%$ of the gas produced by that field regardless of whether it is used, amounting to annual payments of $0.7 \%$ of GDP (Economist Intelligence Unit, 2019). With 640 million standard cubic feet (mmscf) per day contracted compared to a demand of 250 mmscf (Adam \& Boakye, 2014), overly optimistic gas-demand projections were similarly based on supplying 5,000MW alongside industries. ${ }^{60}$ The cost of these LNG contracts (potential excess gas capacity charges of between $\$ 550$ and $\$ 850$ million every

\footnotetext{
${ }^{56}$ Interviews, Senior Planners 1 and 2 and Planning Team, Energy Commission; Senior Manager 2, VRA.

57 Interview, Senior Planner, ECG.

58 Interviews, ex-CEO, GRIDCo; officials, GIZ.

59 Interviews, Senior Planner 1, Energy Commission; Senior Planners, GRIDCo. Contracts were signed for further deals after two initial contracts were cancelled in 2017 (Adam \& Boakye, 2014). 60 Interview, Senior Official 2, World Bank.
} 
year just for Sankofa, according to Adam and Boakye (2014)), led one official to predict that the sector's debt would reach $20 \%$ of GDP, ${ }^{61}$ and others, an accumulated $\$ 12.5$ billion (Economist Intelligence Unit, 2019).

\section{Understanding the underlying politics in Ghana's electricity crises}

\subsection{The conventional understanding}

What are the conventional understandings pushed by the standard reform model for solving these sectoral crises? The most frequently touted solutions assert the importance of getting the prices (the tariffs) and the institutions right by privatising ECG, while further unbundling VRA. The first prescription argues that changes to the tariff will bring the necessary cashflow to ensure the sector's fiscal sustainability. However, there are disagreements here. Some argue that tariffs should be cost-reflective, covering maintenance and operation (Edjekumhene \& Dubash, 2002). ${ }^{62}$ However, Ghana's high levels of electrification, ${ }^{63}$ standing at around $85 \%$ today, render this expensive. As a result of Ghana's unequal regional development, parts of the country do not have sufficient demand to cover grid costs. Moreover, while VRA sells at $\$ 0.06$ per kWh on average, and Bui Power Authority at $\$ 0.8$ per kWh, the IPPs sell at \$0.09-0.14 per kWh (Acheampong, 2016). Additionally, the PPAs are paid in dollars, which have often appreciated against the Ghanaian cedi. With overcapacity and ECG's losses, the full cost-reflective tariff in 2019 would be around $\$ 0.4$ per $\mathrm{kWh}$ - more than double the present non-lifeline household rate of $\$ 0.18$ per-kWh. ${ }^{64}$ Thus, donors and other sectoral experts advocate tariff increases. ${ }^{65}$ Conversely, others argue for decreased tariffs to boost electricity consumption and thereby funds. This argument is also used to deny that there is an oversupply issue: "Nothing wrong with the $[5,000 \mathrm{MW}]$ prediction" the issue is just the price; 66 " $5,000 \mathrm{MW}$ is not enough, there are still plants off and Valco not operating at full capacity". ${ }^{67}$ This argument proposes that tariff adjustments alone are able unlock rapid industrialisation. ${ }^{68}$ However, both groups agree on transparent, independent tariff setting by the PURC. The solution to the sector's underlying financial issues is thus an enhancement of the standard reform model, emphasising formal organisational separation and technocratic independence.

Another advocated element of the standard reform model is the privatising of ECG, or at least the placement of it under a management contract. This introduction of market rationales would supposedly insulate decision making from party politics, ensuring ECG plans its work according to commercial, for-profit motives, translating into better revenue collection, organisational efficiencies and payment to generators. As one interviewee

\footnotetext{
$61 \mathrm{lbid}$.

62 Interviews, Senior Officials 1 and 2, World Bank; officials, GIZ; officials, JICA.

63 Second highest of the continent if one discounts the exceptional cases of South Africa and the small islands of Mauritius, Seychelles and Reunion (Cuesta-Fernández, 2018; Eshun \& AmoakoTuffour, 2016; Kemausuor \& Ackom, 2017).

64 Interview, Senior Official 2, World Bank. The 'lifeline' rate is a subsidised one for poor households.

65 For instance, in 2007 , the World Bank advocated the raising of tariffs to $\$ 0.1$ per kWh to be reflective of system costs.

66 Interview, Senior Planner 1, Energy Commission.

67 Interview, researcher, IEG.

68 Interview, former Minister of Energy.
} 
summarised it: "modernise ECG" and the sector's problems are solved. ${ }^{69}$ Such ideas are not new. In 1983, the Ireland Electricity Supply Board signed a collaborative performance concession agreement with ECG, and in 1994 Électricité de France signed a more extensive concessional performance-management contract (Edjekumhene et al, 2001; Edjekumhene \& Dubash, 2002). Between 2014 and 2019, the USA's Millennium Challenge Corporation organised a management concession agreement with a consortium led by the Philippine utility Manila Electric (Meralco). It fell through over rent-seeking squabbles, which go beyond the scope of this paper. Nevertheless, these attempts illustrate the ongoing belief among international and Ghanaian actors that for-profit motives and performance-based contracts will resolve the sector's fiscal issues. Similarly, this logic sits behind proposals to split VRA into hydropower and thermal operations. Spinning-off, and potentially privatising, the latter will supposedly increase sectoral competition and thereby operational efficiency. ${ }^{70}$

Overall, these proposals are premised on the idea that further formal institutional separations and transparency will solve Ghana's underlying electricity-sector challenges. They would theoretically prevent repetition of past crises as they would mean that tariffs would cover costs and the private and state-owned utility firms would have sufficient finance to afford fuel costs. Moreover, management of the infrastructure and decisions about future generation would be governed by market logics, given further insulation and independence of the regulators PURC and the Energy Commission, and the privatisation of VRA and ECG. This understanding of the problems and solutions for the electricity sector are therefore rooted in the good governance school of thought, which seeks to separate political influence from the sector's policy-making processes through the devolution of power, the separation of governmental functions and the introduction of the private sector. This paper's analysis provides a contrasting view, demonstrating that such formal institutional creations are not allowed to function in Ghana. Independent regulation has never been achieved and formal governance rules, particularly around finance and infrastructure construction, are not practised in reality. This evidence is not easily explained by the recent mainstream literature on rethinking 'standard reform'. It assumes that democratic norms, the adoption of market ideology, middle-income status and relatively developed electricity grids, all of which Ghana has, enable the successful functioning of an electricity system. It therefore offers limited insight into the electricity system's crisis and the politics of policy making behind it. In contrast, this paper offers an explanation using analysis of Ghana's political settlement and ideological rationales.

\subsection{Dum-sor: the product of competitive politics?}

While clearly triggered by particular external events, political factors drove fiscal problems that caused the dum-sor crises' depth and longevity. These fiscal issues were chiefly produced by different governments intervening to keep tariffs low, constructing inefficient infrastructure and redirecting budgets from the utilities towards short-term electoral concerns. In particular, the large deficit caused by the 2012 election limited government support for fuel purchases (IMF, 2013, p 4). The dynamics of Ghana's political settlement therefore negatively influenced the finances of government and utility companies, in turn

\footnotetext{
69 Interview, ex-CEO, GRIDCo.

70 Interview, former Minister of Energy.
} 
meaning that they were in a poor fiscal position at the moment when they needed to allocate funds for light-crude fuel. Unpopular policies like tariff increases or cuts to government programmes to cover bills have proven near impossible to sustain, even when they might slowly work to build a financially resilient electricity system; the slow grind of achieving longterm sustainability has been ditched in favour of short-term appeasement, overriding formal institutional separations and market mechanisms. The pressures created by Ghana's competitive, unstable political settlement created short-termism; the electoral focus undermined the government's financial position and that of its state agencies, thereby transforming an initial fuel shortage into the four-year dum-sor. Measures to get 'the prices and institutions right' have been overwhelmed by deeper political objectives.

\subsection{Oversupply: the expectation to deliver?}

The political settlement also helps explain the oversupply crisis, which is partly rooted in electricity's historic status in Ghana. Through the Volta River Project and the Akosombo Hydroelectric Dam, founding President Nkrumah equated electricity with development and seeded ideas about the technology as a citizenship right (Cuesta-Fernández, 2018; MacLean, Gore et al, 2016; MacLean, Bob-Milliar et al, 2016). This idea was cemented by President Rawlings (1979, 1981-2001), who used electrification projects to build a voter base. MacLean, Bob-Milliar et al (2016) argue that, by 2010, this had resulted in a norm that providing electricity was an unquestionable governmental responsibility, a basic test of competence. Thus, dum-sor crashed the incumbent NDC's popularity. News coverage ("the first middle class revolution [in Ghana]" ${ }^{1}$ ), protests and popular slogans like 'no electricity, no vote' captured the popular mood (Destrée, 2019). Interviewees reported that most diagnoses of $d u m$-sor among the elite and the press blamed generation capacity and not fuel, as demonstrated above. Consequently, fear grew, particularly within the NDC, when by 2014 the Nigerian gas pipeline's restoration and new plants did not stop power cuts. With the approaching 2016 election, politicians pushed rapid implementation of the aspirational $5,000 \mathrm{MW}$ target: "central government was hot, the election was approaching". ${ }^{72}$ Panic buying followed, ${ }^{73}$ with normal channels of procurement suspended and the official advice and regulatory processes of the Energy Commission sidelined. GRIDCo, the agency mandated to coordinate generation expansion and ensure stability, was excluded from discussions. Unlike the orderly commissioning of former IPPs featuring lower tariffs, ${ }^{74}$ and involving all the utilities and regulators, deals were rushed, even through parliament (Kasapa FM, 2015). ${ }^{75}$ Therefore, concern about the 2016 election drove a short-termism demanding "emergency decisions" that suspended the usual processes. ${ }^{76}$ Ghana's competitive political settlement, and the need of the incumbent coalition to maintain power by winning elections, thus drove a rash boom in unnecessary IPP contracts, pushing the sector into a future debt crisis.

\footnotetext{
71 Interview, researcher, Centre for Democratic Development.

72 Interview, Senior Planner 2, Energy Commission.

73 Interview, Senior Planner 1, Energy Commission.

${ }^{74}$ As happened in 1998 with the Takoradi International Power Company (TICO) (220MW), in 2010 with Sunon Asolgi (200MW) and in 2012 with CENIT (126W).

75 Interview, former Minister of Energy.

76 lbid.
} 
Alongside electoral panic, an additional likely motivation for the rapid contracting of power generation was rent seeking. The signing of so many IPPs, with relatively little scrutiny, presented a major opportunity to divert public funds to private profit. One particularly controversial deal involved the Ameri plant, which a newspaper investigation claimed was overpriced by $\$ 290$ million (Bakke Foss et al, 2016). Many interviewees in the sector reported that the IPPs had political connections; 77 "every minister in the cabinet had their own pet project" ${ }^{78}$ Indeed, this use of IPPs for rent seeking continued post-2016. Again the Ameri plant caused scandal, ${ }^{79}$ potentially costing $\$ 1$ billion and involving current President Akufo-Addo's close circle (Antwi, 2019). ${ }^{80}$ As established above, such rent seeking is strongly incentivised by Ghana's political settlement, as it enables the gathering of electioneering costs and channels support to key coalition members. Short-term political interventions therefore overrode the good governance model whereby sectoral experts' demand-driven modelling drove independent longer-term planning and regulatory processes.

\subsection{The overlooked influence: high-modernist ideology}

However, political-settlement explanations exclusively focusing on strategic interests about keeping power do not wholly account for the oversupply crisis. Such interests do not account for the fact that this boom in power plants, though not following the timeline or technologies of the 2010 electricity act (detailed above), did meet its 5,000MW target. According to interviewees, the target stemmed from the NDC's manifesto, which "included a lot of industrial activity", ${ }^{81}$ more export-orientated industrial growth and universal electrification. ${ }^{82}$ The National Development Planning Commission helped turn this into an updated national growth plan (NDPC, 2010, p 61). ${ }^{83}$ Inter alia the plan envisioned VALCO, an aluminium smelter launched through Nkrumah's Volta River Project (Miescher, 2014), returning to full capacity, and the reopening of factories closed in the 1990s, such as a juice factory and glass smelter privatised under President Rawlings. ${ }^{84}$ Despite the lack of economic justification for such a scenario, given the known difficulties of what the literature terms 'late' late 21st century industrialisation (Behuria, 2019), and in contrast to Ghana's unsuccessful history of industrialisation attempts, the Energy Commission translated these ambitions into forecasts, describing the processes as: "you want to build a skyscraper - we will give the projections". ${ }^{85}$ This planning process occurred in parallel to that conducted by the utilities. As stated above, a target of 5,000MW was at odds with the forecasts of the Strategic Energy Plan of 2006 and those of VRA and GRIDCo. Indeed, the latter weren't involved in the plans, concluding that the 5,000MW figure was "a matter of politics"; 86 it "was done without recourse to analysis. We [VRA] know demand on the grid [and this was] far above any

\footnotetext{
77 Interviews, Senior Official, MiDA; Senior Officials 1 and 2, World Bank; Senior Planner 1, Energy Commission.

${ }_{78}$ Anonymous informant, Accra.

79 Interview, researcher, IEG.

$80 \mathrm{lbid}$

81 Interviews, senior and junior officials, Renewables, Ministry of Energy.

82 Interview, former Minister of Energy.

83 Interviews, Senior Planners 1 and 2 and Planning Team, Energy Commission.

84 Interviews, Senior Planners 1 and 2, Energy Commission.

85 Interview, Senior Planner 2, Energy Commission.

86 Interview, Senior Planners, GRIDCo.
} 
realistic reserve margin". ${ }^{87}$ Key electricity-system experts therefore disagreed about whether increased electricity generation would animate industrialisation, whether to believe that demand will inevitably follow exponential increases in supply.

According to Dye $(2016,2018, p 1 ; 2020 a)$, this type of linear, technologically centric thinking in the electricity sector has roots in the high-modernist logics coined by Scott (1998): they suggest an overriding belief in technology to create socioeconomic change and overconfidence in top-down planning expertise. Modernist ideologies have historic roots in Ghana, and are particularly associated with President Nkrumah and the scale of ambition and optimism of his Volta River Project (Hoag, 2013). Moreover, a similar belief in the megawatt to create development by itself is visible elsewhere, for example in Rwanda's and Tanzania's rapid building of power plants (Dye, 2018, p 4; 2020a). The overruling of experts' advice and forecasts suggests, at some level, an ideological belief in the power of megawatts to deliver economic demand and development, a confidence that technology could overcome structural constraints. Ideology, alongside the strategic interests of Ghana's political settlement, consequently drove the country's oversupply crisis. This analysis consequently refutes Whitfield's and others' assertion that policy making in Ghana is not influenced by ideology, demonstrating that ideas sit alongside strategic interests as influencers in Ghana's policymaking.

\section{Conclusion: the standard reform model and the undermining of electricity planning}

How should we understand electricity crises and the sector's policymaking? The mainstream explanation asserts that there has been an insufficient application of the standard reform model: to fix Ghana, we just need to 'get the prices and institutions right'. This explanation sees solutions in the privatisation of utilities, and thereby the introduction of further commercialised, for-profit institutional norms, alongside greater regulatory independence. Ghana should also have the preconditions to make such a system work, according to the World Bank's assessment of electricity-sector reform. The factors enabling successful standard reform implementation identified by Foster and Rana (2019) include democratic, competitive elections and support for market economics, both of which Ghana demonstrates, not least given that both parties have pursued the creation of independent regulation, the introduction of market mechanisms, corporatisation and unbundling in the electricity sector. ${ }^{88}$ Gore et al (2019) rank Ghana as having implemented 5.5/8 of the standard reform policies.

This paper has contrasted this focus on institutions, prices and the surface-level function of the electricity sector with a deeper understanding of the politics of policy making in the sector. This analysis has linked Ghana's two crises of absence and abundance to the country's underlying political settlement and high-modernist ideological rationales: the dumsor crisis's immediate triggers were external, resulting from the pipeline break and drought, but its depth and length were caused by the inability of ECG and VRA, and hence the state, to pay for fuel. Similarly, pre-election panic, alongside a dose of high-modernist ideology and opportunities for rent seeking, led to the costly boom in power plants. Thus, the paper has

\footnotetext{
87 Interview, Senior Planner 1, VRA.

${ }^{88}$ Admittedly, Ghana has only had limited decentralisation and has no history of transparent tariff setting, factors Foster and Rana also identify as key for enabling standard reform.
} 
demonstrated that attempts to 'get the prices and institutions right' have proved impossible, at least thus far. This is evident in the inability to formally separate functions and ensure their operational independence, best demonstrated by the PURC, the tariff setting body. It is also evident in other areas - such as water - where utility companies have undergone good governance reforms: the ability of the water utility to set prices and operate independently was overwhelmed by party-political drivers (Hirvi \& Whitfield, 2015). Ghana's utility companies are frequently unable to implement their technical recommendations because of political pressure, or are formally or informally overruled by the Ministry of Energy and the Presidency. Equally, the corporatising and commercialising of the state utilities was supposed to create efficiency, by making them companies with for-profit motivations. However, this has seemingly done little to change their practices, whether that be ECG's tariff collection or the sector's financial sustainability. De facto state powers render formal rules and the honouring of contracts relatively insignificant.

Fundamentally, then, this paper has demonstrated that analysis of institutional change shouldn't merely focus on the formal policies and organisations created to govern the electricity sector, nor should it read significant explanatory value into the presence of generic identifiers such as elections, 'democratic norms' or political competition. Rather, any analysis should appreciate the societal manifestation of power and the way this shapes the political status quo; analyses of the wider political settlement reveal the pressures on policy making and the way in which formal institutions may be overwhelmed. The very competition and democracy identified by Foster and Rana (2019) as enablers of reform are consequently revealed as detrimental to long-term planning and the inclusion of expertise. Additionally, and echoing the author's work elsewhere (Dye, 2020a), the paper asserts that ideology matters in policy making and should be considered an influence alongside strategic, more materialist interests.

Arguably the analysis here also questions the benefits of the good governance model and why it remains so influential, particularly over electricity-sector thinking. In Ghana, the introduction of standard reform policies appears to have increased opportunities for electricity distortion. This is most evident in the introduction of IPPs, which may have made the bypassing of long-term planning easier, given that the VRA did not support, and would have been unable to enact, the construction of so many plants. Further, rather than increasing efficiency within the sector and bringing down costs, these deals have offered new chances for rent seeking. IPPs also incentivised high tariffs that would benefit investors and connected politicians, primarily punishing the utilities. Indeed, the increasing evidence of particularly high fiscal obligations, caused by booms in IPPs elsewhere on the continent, ${ }^{89}$ evidences the need to reappraise the policy's riskiness. Moreover, the continued focus on implementing the standard reform model also contrasts with pressing 21 st century developmental challenges. Should unbundling institutions, introducing competition and market logics remain a top priority when decarbonisation of electricity grids and the achievement of universal access have not been reached?

${ }^{89}$ For example, in Rwanda (Dye, 2020a). 


\section{References}

Abdulai, A.-G. and Hickey, S. (2016). 'The politics of development under competitive clientelism: insights from Ghana's education sector'. African Affairs 115, 44-72. adv071.

Acemoglu, D. and Robinson, J.A. (2013). Why Nations Fail: The Origins of Power, Prosperity, and Poverty. London: Profile Books.

Acheampong, T. (2016). 'The implications of changing power generation mix for energy pricing and security in Ghana'. SSRN Electronic Journal. 10.2139/ssrn.2763284

Adam, M.A. and Boakye B., (2014). Ghana Gas, Questionable Deals and the National Interest: How Ghana's Quest for Energy Security faces Imminent Danger.

Ahlborg, H., Boräng, F., Jagers, S.C. and Söderholm, P. (2015). 'Provision of electricity to African households: the importance of democracy and institutional quality'. Energy Policy 87, 125135.

Antwi, P. (2019). 'Ameri scandal cages Akufo-Addo between party \& family'. GhanaGuardian. https://ghanaguardian.com/ameri-scandal-cages-akufo-addo-between-party-family

Bakke Foss, A., Wideroe, R.J. and Henden, H. (2016). 'Ghana's Minister of Power signed deal with a man from Oslo wanted for fraud and organized crime - the deal is worth 510 million dollars'. VG, 29 August.

Banful, A.B. (2011). 'Do formula-based intergovernmental transfer mechanisms eiminate politically motivated targeting? Evidence from Ghana'. Journal of Development Economics 96, 380390.

Bayliss, K. and Cramer, C. (2003). 'Development policy in the twenty-first century: beyond the PostWashington Consensus'. In Fine, B., Lapavitsas, C. and Pincus, J. (eds), Development Policy in the Twenty-first Century: Beyond the Post-Washington Consensus. London: Routledge.

Behuria, P. (2019). 'Twenty-first century industrial policy in a small developing country: the challenges of reviving manufacturing in Rwanda'. Development and Change 50, 1033-1062.

Behuria, P., Buur, L. and Gray, H. (2017). 'Studying political settlements in Africa'. African Affairs 116, 508-525.

Briggs, R.C. (2012). 'Electrifying the base? Aid and incumbent advantage in Ghana'. Journal of Modern African Studies 50, 603-624.

CDD and WFD (2018). The Cost of Politics in Ghana. Centre for Democracy and Development and the Westminster Foundation for Democracy.

Chang, H. (2006). The East Asian Development Experience: The Miracle, the Crisis and the Future. London: Zed.

Chineke, T.C. and Ezike, F.M. (2010). 'Political will and collaboration for electric power reform through renewable energy in Africa'. Energy Policy 38, 678-84.

Cuesta-Fernández, I. (2018). 'Kilowatts, megawatts and power: electric territorialities of the state in the peripheries of Ghana and Tanzania'. PhD Thesis. University of Edinburgh.

Destrée, P. (2019). 'Power flashes: the political and visual cultures of electricity in Accra, Ghana'. PhD thesis, University College London.

Dye, B.J. (2016). 'The return of "high modernism"? Exploring the changing development paradigm through a Rwandan case study of dam construction'. Journal of Eastern African Studies 10, 303-324.

Dye, B.J. (2018). 'The politics of dam resurgence: high modernist statebuilding and the emerging powers in Africa'. DPhil Thesis. University of Oxford.

Dye, B.J. (2020a). 'Ideology matters: political machinations, modernism, and myopia in Rwanda's electricity boom'. Energy Research \& Social Science 61. 
Dye, B.J. (2020b). 'Continuity or change in the infrastructure turn? Reform of the technicians' realm in a World Bank dam'. European Journal of Development Research 32, 627-651.

Dzawu, M.M. (2020). 'Ghana's power abundance turns to burden as energy debts mount'. Bloomburg, 10 September.

Economist Intelligence Unit (2019). Infrastructure Reform mitigates Energy Sector Dysfunction. London: Economist Intelligence Unit.

Edjekumhene, I., Bawa Amadu, M. and Brew-Hammond, A. (2001). Power Sector Reform in Ghana: The Untold Story. Kumasi Institute of Technology and Environment (KITE).

Edjekumhene, I. and Dubash, N.K. (2002). 'Ghana: achieving public benefits by default'. In Dubash, N.K. and Bouille, D. (eds), Power Politics: Equity and Environment in Electricity Reform. Washington DC: World Resources Institute.

Energy Commission (2006). Strategic National Energy Plan 2006-2020. Main Report. Accra: Energy Commission.

Energy Commission, Strategic Planning and Policy Division (2014). National Energy Statistics 2000 2013. Accra: Energy Commission.

Energy Commission, Strategic Planning and Policy Division (2019). National Energy Statistics 20092018. Accra: Energy Commission.

Eshun, M.E. and Amoako-Tuffour, J. (2016). 'A review of the trends in Ghana's power sector'. Energy, Sustainability and Society 6,1. https://doi.org/10.1186/s13705-016-0075-y

Foster, V. and Rana, A. (2019). Rethinking Power Sector Reform in the Developing World. Washington DC: World Bank.

Gore, C.D., Brass, J.N., Baldwin, E. and MacLean, L.M. (2019). 'Political autonomy and resistance in electricity sector liberalization in Africa'. World Development 120, 193-209.

Gray, H. (2018). Turbulence and Order in Economic Development: Institutions and Economic Transformation in Tanzania and Vietnam. Oxford: Oxford University Press.

Gray, H. and Khan, M. (2010). 'Good governance and growth in Africa: what can we learn from Tanzania?'. In Padayachee, V. (ed.), The Political Economy of Africa. London: Routledge.

Gregory, J. and Sovacool, B.K. (2019). 'Rethinking the governance of energy poverty in Sub-Saharan Africa: reviewing three academic perspectives on electricity infrastructure investment'. Renewable and Sustainable Energy Reviews 111, 344-354.

Hirvi, M. and Whitfield, L. (2015). 'Public-service provision in clientelist political settlements: lessons from Ghana's urban water sector'. Development Policy Review 33, 135-158.

Hoag, H.J. (2013). Developing the Rivers of East and West Africa: An Environmental History. London: Bloomsbury.

IMF (2013). Ghana: 2013 Article IV Consultation. Country Report 13/187. Washington DC: IMF.

Kapika, J. and Eberhard, A.A. (2013). Power-sector Reform and Regulation in Africa: Lessons from Kenya, Tanzania, Uganda, Zambia, Namibia and Ghana. Cape Town: HSRC Press.

Kasapa, F.M. (2015). 'AMERI deal was rushed through Parliament - MP'. GhanaWeb, 15 December.

Kemausuor, F. and Ackom, E. (2017). 'Toward universal electrification in Ghana'. Wiley Interdisciplinary Reviews: Energy and Environment 6, e225.

Khan, M. (2010). Political Settlements and the Governance of Growth-enhancing Institutions. School of Oriental and African Studies Working Paper 98. London: SOAS.

Lavers, T. and Hickey, S. (2016). 'Conceptualising the politics of social protection expansion in low income countries: the intersection of transnational ideas and domestic politics'. International Journal of Social Welfare 25, 388-398. 
Lee, A.D. and Usman, Z. (2018). Taking Stock of the Political Economy of Power Sector Reforms in Developing Countries. Policy Research Working Paper 8518. Washington DC: World Bank Group.

MacLean, L., Bob-Milliar, G.M., Baldwin, E. and Dickey, E. (2016). 'The construction of citizenship and the public provision of electricity during the 2014 World Cup in Ghana'. Journal of Modern African Studies 54, 555-590.

MacLean, L., Gore, C., Brass, J. and Baldwin, E. (2016). 'Expectations of power: the politics of statebuilding and access to electricity provision in Ghana and Uganda'. Journal of African Political Economy and Development 1, 103-134.

Miescher, S.F. (2014). "Nkrumah's baby": the Akosombo Dam and the dream of development in Ghana, 1952-1966'. Water History 6, 341-366.

Ministry of Energy (2010). National Energy Policy. Accra: Ministry of Energy.

Mohan, G., Asante, K.P. and Abdulai, A.-G. (2018). 'Party politics and the political economy of Ghana's oil'. New Political Economy 23, 274-289.

National Development Planning Commission (NDPC) (2010). Ghana Shared Growth and Development Agenda (GSGDA), 2010-2013. Vol I: Policy Framework. Accra: NDPC.

North, D.C. (1990). Institutions, Institutional Change, and Economic Performance. Cambridge: Cambridge University Press.

North, D.C., Wallis, J.J. and Weingast, B.R. (2009). 'Violence and the rise of open-access orders'. Journal of Democracy 20, 55-68.

North, D.C., Wallis, J.J. and Weingast, B.R. (2013). Violence and Social Orders: A Conceptual Framework for Interpreting Recorded Human History. Cambridge: Cambridge University Press.

Nugent, P. (1999). 'Living in the past: urban, rural and ethnic themes in the 1992 and 1996 elections in Ghana'. Journal of Modern African Studies 37, 287-319.

Oxford Business Group (2017). 'Projects in pipeline to improve grid stability in Ghana's utilities sector'. In The Report: Ghana 2017. Oxford: Oxford Business Group.

Rodrik, D. (2006). 'Goodbye Washington Consensus, hello Washington confusion? A review of the World Bank's economic growth in the 1990s: learning from a decade of reform'. Journal of Economic Literature 44, 973-987.

Rupp, S. (2013). 'Ghana, China, and the politics of energy'. African Studies Review 56, 103-130.

Scott, J.C. (1998). Seeing like a State: How Certain Schemes to Improve the Human Condition have Failed. New Haven CT: Yale University Press.

Whitfield, L. (2009). "“Change for a better Ghana”: party competition, institutionalization and alternation in Ghana's 2008 elections'. African Affairs 108, 621-641.

Whitfield, L. (2018). Economies after Colonialism: Ghana and the Struggle for Power. Cambridge: Cambridge University Press.

Wolf, S., Fuest, V. and Asante, F. (2007). 'Water and electricity sector reforms in Ghana: back on track?'. International Journal of River Basin Management 5, 37-47.

World Bank (1993). The World Bank's Role in the Electric Power Sector: Policies for Effective Institutional, Regulatory, and Financial Reform. Washington DC: World Bank.

World Bank (2012). Financial Review of the Power Sector. Washington DC: World Bank.

World Bank (2013). Republic of Togo: Togo Energy Sector Policy Review - Review of the Electricity Sub-sector. Report ACS499. Washington DC: World Bank. 
World Bank (2018). International Development Association Project Appraisal Document for the Ghana Energy Sector Transformation Initiative Project. Project Document PAD2576. Washington DC: World Bank

World Bank Group (2018). Ghana Priorities for Ending Poverty and Boosting Shared Prosperity [available at http://hdl.handle.net/10986/30974]. Accessed: $2^{\text {nd }}$ November 2020. 